Thorpe, A. (In press) Educational leadership development and women: insights from critical realism. International Journal of Leadership in Education.

\title{
Educational leadership development and women: insights from critical realism.
}

Anthony Thorpe

School of Education, University of Roehampton, London, UK

Dr Anthony Thorpe * Corresponding author

Senior Lecturer - Leadership and Management

School of Education

University of Roehampton

London

United Kingdom

Email a.thorpe@roehampton.ac.uk

$+44(0) 2083923895$

The article below has been accepted by the International Journal of Leadership in Education (January 2018) and is the pre-proof copy/ author version. 


\title{
Educational leadership development and women: insights from critical realism
}

\author{
Abstract \\ A considerable amount of research has been conducted into women's experiences of \\ leadership in the education sector with calls to further promote equality, increase diversity \\ and foster inclusion but ways forward seem less easy to implement with the same \\ experiences and frustrations continuing to emerge. This article applies insights from critical \\ realism to educational leadership development to seek a fuller understanding as to why \\ these concerns remain and how they might be addressed. The article begins by considering \\ barriers to women attaining leadership positions and accessing leadership development \\ including those posed by the 'leadership turn' and new managerialism. Some ideas behind \\ critical realism are briefly introduced before exploring the possible implications for \\ educational leadership development. It is argued that a fundamental challenge to, and \\ changing of, the dominant concept of leadership must take place before progress can be \\ made. Directions are proposed for critical realist work in the theory and practice of \\ educational leadership development and the wider field.
}

Keywords: critical realism, educational leadership, leadership development, structures, women in administration 
Research conducted into women's experiences of leadership in the education sector has led to calls to further promote equality, increase diversity and foster inclusion and yet, ways forward seem less easy to implement with the same experiences and frustrations continuing to emerge often around discrimination and stereotyping (Coate, Kandiko Howson, \& de St Croix, 2015; Fuller, 2017; Morley, 2013; Showunmi, Atewologun, \& Bebbington, 2015). The article draws upon insights from critical realism, which have been little used previously in the field, to seek a fuller understanding of why these concerns remain in relation to educational leadership development and identify appropriate ways forward. Critical realism is a movement in philosophy, distinct from critical theory, that seeks to move beyond surface level experiences and events to identify the underlying structures and mechanisms that generate these experiences within specific contexts (Archer et al., 2016; Gorski, 2003; Shipway 2011). It may be particularly well placed to analyse leadership environments and practices to reveal patterns and structures not previously considered that could influence approaches to educational leadership development and women.

The article seeks to raise questions and identify possibilities rather than offering simplistic answers with pretensions to conclusiveness. It begins by considering barriers to women attaining leadership positions and accessing leadership development including those posed by new managerialism and the 'leadership turn'. The ideas behind critical realism are then introduced including the understanding of ontology and structures. The final sections explore some possible critical realist insights for educational leadership development programmes and women before identifying further theoretical work and empirical research.

Two caveats need stating here. First, the article is written from a UK university setting with its concerns and content and outlook drawing largely on UK, Irish, North American and Australasian literature. What might be said to be similar about these settings is that they are economically developed, English speaking countries where neo-liberal reforms have tended 
to dominate in educational settings. They are also contexts in which equality, diversity and inclusion are widely accepted (however differently that acceptance may be understood) in comparison with places where their promotion is met with widespread social disapproval and may be legally constrained. The countries also report common patterns of underrepresentation of women in the senior levels of organizational hierarchies. A second caveat acknowledges a tension within literature that sometimes presents leadership as a practice or a theory and at other times as a synonym for bureaucratic positions towards the top of an organization's hierarchy or an element in a post-holder's title (Senge, 1999). Much of the leadership development literature discussed below tends to see it as preparation for, and ways of accessing, formal posts in organizational hierarchies.

\section{Barriers to women attaining leadership positions and leadership development}

There has been a growing interest in gender and leadership in educational organizations with much of the literature having been published in the last decade (Thorpe, 2016). The underrepresentation of women in senior leadership positions in educational organizations remains a significant issue. In UK schools, for example, most teachers are female but most heads of secondary schools are male and the proportion of male heads in primary schools is large in comparison to the overall number of women in primary teaching though the proportion of female head teachers and deputy head teachers is growing (Fuller, 2017; Smith, 2011). Similar patterns of disproportionate representation are found in leadership positions in the university sector (Beddington 2009; Coate et al., 2015; Shepherd, 2017) and organizations outside of education such as corporations in the USA (Catalyst, 2016; Ely, Ibarra Insead, \& Kolb, 2011).

Barriers to women's accessing these higher positions in organizations are increasingly identified as 'second generation forms' of gender bias that contribute to the often mentioned 'glass ceiling' despite the introduction of legislation, institutional policies and women only development programmes all aimed at promoting equality and inclusion (Ely et al., 2011). 
The same experiences and frustrations emerge across generations with concerns about pervasive discrimination and stereotyping (albeit in subtler forms) including, for example, a homosocialibility operating in appointments creating a homogeneity in those holding leadership positions in schools (Blackmore, Thompson, \& Barty, 2006; Showunmi et al., 2015).

Yet one view identifies women as practicing a different form of leadership from men making them better leaders for that distinctiveness. Whilst stereotypical male styles are perceived to be favoured by governing bodies and appointment panels, stereotypical female styles are increasingly seen by researchers as more desirable in practice (Griffiths, 2009; Grogan \& Shakeshaft, 2011). Such views challenge the homogeneity in the theory and practice of educational leadership (Blackmore, 2010) though talk of 'the female advantage' may also contribute to unhelpful binds and limits for women (Billing \& Alvesson, 2000; Morley, 2013). Focusing on strategies for the mid-career development of academic women working at UK higher education institutions, Coate et al. (2015) encourage the reappraisal of dominant ideas about recognition, reward and valuing the work and talents of females whilst specifically recommending institutions provide targeted support for development.

Leadership development opportunities are perceived by women and men to be important in obtaining promotion but women have long reported facing greater barriers to their advancement within the hierarchy (Lyness \& Thompson, 2000). Whilst women often find mentoring supports their advancement, they frequently identify greater challenges than men in securing mentors to enable them to take advantage of this (Dever et al., 2008; Ibarra, Carter, \& Silva, 2010; Moorosi, 2012). However, the narrowness of leadership development in many contexts leads to the dominance of skills building at the expense of approaches drawing on life experiences prompting calls for the exploration of the multiple meanings and alternative discourses of leadership development (Boerema, 2011; Mabey, 2013). Griffiths (2009) speaks of the need to create spaces and supportive environments specifically for 
women managers in universities to discuss problems through the use of action sets, coaching and women-only training. Yet comparatively little research on gender specific leadership programmes exists in educational contexts (Barnard, Arnold, Bosley, \& Munir, 2016), though there have been some explorations of women-only support networks (Coleman, 2010).

Ely et al. (2011) argue that women only leadership programme cohorts in the USA are helping to dismantle barriers through creating safe spaces for each participant to explore her own identity and integrating it into her core-self. Women are provided with opportunities to identify and challenge the second-generation barriers to their progress to higher leadership positions and within their practice (see also Debebe, Anderson, Bilimoria, \& Vinnicombe, 2016). These programmes are characterised as engaging in more active learning and offering greater developmental support compared with general programmes dominated by concerns with knowledge transmission and the creation of networks for business (Sugiyama, Cavanagh, van Esch, Bilimoira, \& Brown, 2016). Debebe et al. (2016, p.235) emphasise the role of 'transformation learning' that 'involves deep change and discontinuity with past patterns'. They advocate deploying intersectional perspectives in programmes to explore the paradox that many women feel about both being enabled and restricted in their leadership practice. The authors also highlight the importance of embedding customised programmes in organizations with the support of senior leaders to challenge and change the existing structures and practices which often work against women.

The debates around women only leadership development programmes include concerns that they may continue and reinforce the current situation through 'the add women and stir' approach that does not take account of gender or the 'fix-the-women' approach that characterises women as problems to be addressed (Cullen-Lester, Woehler, \& Willburn, 2016; Ely et al., 2011; Morley 2013). Both formal and informal mentoring can also replicate existing power relationships and established views and practices regardless of whether 
females or males are involved (Colley, 2001; McKeen \& Bujaki, 2007), for example, through the transmission of dominant, taken-for-granted cultures of performativity in universities (Devos, 2008).

Hoobler, Lemmon, and Wayne (2014) argue that 'benevolent sexism' also operates as a barrier to women accessing leadership development opportunities. Their research at a U.S. Fortune 500 firm identifies how biased manager perceptions of women subordinates as having lower career motivation than men negatively influenced how, and what, development opportunities were allocated to women. The discrimination occurred regardless of the manager's gender so adding to the list of 'ambiguous, subtle discrimination that women face in the workplace, such as microinequities in interpersonal treatment' (Hoobler et al., 2014, p.706) implying that an increase in the number of women in higher positions in organizations will not alone bring about change for women in general.

The discussions above indicate that the topic of women and leadership development should not be considered in isolation from the dominant theories of leadership and the discursive patterns that position it (Elliot \& Steed, 2017). The next section considers two further barriers, namely new managerialism and the turn to leadership in educational organizations, which contribute to the taken-for-granted theories and discourses that frame educational leadership development.

\section{New managerialism and the leadership turn in education}

Critical stances towards leadership, often drawing on critical theory, problematize and provide alternatives to dominant ideas in theory and practice rejecting techniques and legitimizations which favour powerful elites whilst disadvantaging the poor and marginalized (Alvesson, Bridgman, \& Willmott, 2011; Corson, 2000). Such approaches have identified 'new managerialism' as another barrier to women seeking to accessing senior positions in 
the hierarchy and practising leadership (Lynch, 2014; Thrupp \& Willmott, 2003). New managerialism applies to the public sector the Taylorist presumptions of the inevitability of progress through economic production and technological innovation requiring workers' compliance and managers' freedom to command and control. Management is made a value of the first order with managers posited as professionals holding specific and transferable skills and concepts. Managers will bring social harmony through technical means though this deprives others in civil society of decision making powers. A neo-liberal 'for profit' stance is assumed involving a reconstruction of the welfare state through the development of quasimarkets for 'services' and 'new public management'. New managerialist language privileges outputs and performance, performance management and performance indicators, competition and choice, contractual relationships, the decentralization of budgets and the emphasis of line manager authority. All these concepts are presented as timeless and context free.

As gendered divisions of labour often place the moral imperative to care upon women in education and elsewhere, women's work-life balance is most deeply affected by seeking, attaining and maintaining senior positions (Barrett \& Barrett, 2011; Guillaume \& Pochic, 2009; O’Brien, 2007; Runte \& Mills, 2004). Critical examinations of new managerialism's influence in education in Ireland have uncovered how its integration with neo-liberal ideas and policies create a 'careless' culture leading to the reconstruction of education leaders (Grummell, Devine, \& Lynch, 2009; Lynch, Grummell, \& Devine, 2012). The placing of great importance on long work hours, strong competitiveness and intense organizational dedication mitigates against those with caring commitments especially primary care responsibilities.

The neo-liberal citizen is careless and commercially ever ready to make an investment with a view to personal profit. A 'cosmopolitan worker built around a calculating, entrepreneurial, detached self...who is unencumbered by care responsibilities and is free to play the 
capitalist games' (Lynch et al., 2012, p. 83). The neo-liberal primacy of transactions around profitmaking and financial investment means that the unpaid labour in families and communities is not seen to count and so misrecognised as a burdensome and irritating cost. The adoration of profit and its investment characterises money spent on public services, such as teachers' salaries, as wasteful and draining.

Women, in particular, find the ever increasing demands of new managerialism difficult to reconcile with the sense of community and caring within education leading to feelings of isolation and of not being taken seriously as leaders. Lynch et al. (2012) also refer to 'safe solutions' to gender discrimination in schools that do not change the way they work or challenge the existing power relations which often have led to that discrimination so contributing to the continuance of women's frustrations around educational leadership. For example, traditionally excluded groups, including women, are given positions with limited power and prestige compared with those posts held mainly by men. Alternatively, once prestigious posts are now transformed into less powerful roles, such as the head teacher in the English 'academised' school system who is a now a subordinate of the executive head teacher or academy chain chief executive officer.

The reductionism that privileges concerns with assessment and league tables to the exclusion of social justice and democracy makes the 'leadership turn' in educational organizations a further barrier (Bogotch \& Shields, 2014; Gunter \& Thompson, 2009). There was optimism that adopting leadership theory and practice would take educational management beyond a narrow, mechanistic pre-occupation with implementation to encompass matters of ethics, vision and social justice (Corson, 2000; Glatter, 2006; Grace, 1995). Yet what emerged from the 1990s onwards was rather different as UK governments used the 'leadership' label in their policy rhetoric to implement managerialist reforms (O'Reilly \& Reed, 2010; Torrance \& Humes, 2015). These government sponsored forms of leadership appear to deploy transformational leadership discourses promising greater 
autonomy and change but prescribing the goals for institutions and, increasingly, the ways to achieve them through privatisation and private profit with claims of improvement through quantifiable indicators stifling democratic debate and the voices of local communities (Gunter, 2011).

Morley (2013) writes of women and the leadership turn in higher education. She identifies examples of misrecognition and gender bias in the managerial university reinforcing masculine constructions and hegemonies in line with the 'think manager, think male' phenomenon (Schein, 1973) despite the presence of some women leaders. The turn is neither neutral nor accidental but a politically and ideologically motivated emphasis on the individual leader to divert attention from the commercial and value shift in the sector. As an alternative to the unbounded individualism of heroic leadership and reified definitions restricting leadership to those holding formal positions in the hierarchy, leadership is conceived as a social practice in which all can participate collaboratively, critically and democratically (for example, Capper \& Young, 2014; Eacott, 2015; Gunter, 2011; Santamaría \& Gaetane, 2014).

Intersectionality has been used from a critical stance to disrupt taken-for-granted views by taking into account the sociocultural dynamics of gender, race and social justice related to individual educational leaders (Arnold \& Brooks, 2013). As an interdisciplinary approach to analyzing the concurrent impacts of social structures, intersectionality uncovers how belonging to multiple exclusionary social categories helps to understand the position of women and their struggles in accessing equality (Debebe et al., 2016; Martinez Dy, Martin, \& Marlow, 2014). Intersectional analysis has also identified the need for more collaborative dialogue in, and a re-appraisal of, educational leadership development programmes as well as revealing unexpected ways in which women appear to obtain greater benefits from programmes than men (Moorosi, 2013; Showunmi et al., 2015). 
Critical approaches to the field have successfully debunked many taken-for-granted managerialist approaches but ways forward again seem less clear with calls for more concepts and tools which will disrupt and change those idealisations of leadership that support continuing inequity (Blackmore, 2010; Niesche \& Keddie, 2011; Wilkinson \& Eacott, 2013). Others urge the recognition of the complex interplay of agency and structure within the specific contexts of educational institutions that enable, delimit and thwart educational leadership (Close \& Raynor, 2010; Glatter, 2006). Making the link between the barriers of the leadership turn and new managerialism clearer, O'Reilly and Reed (2010) draw on critical realism to identify 'leaderism' as a disguise of new managerialism. Public services are re-oriented towards the consumer-citizen through the appropriation and reconstitution of leadership as a social and organisational technology. This ‘leaderism' offers leadership as an 'organisational panacea' creating new structures for what it is to be a leader. The next section introduces critical realism, which is distinct from critical theory (Shipway, 2011), as a way to consider ideas which may be only partially understood through other established philosophies and methodological approaches.

\section{Critical realism: ontology, structures and emancipation.}

Critical realism is an established post-positivist philosophy of science developed by Roy Bhaskar (1944-2014) amongst others. It seeks to move beyond the surface level experiences to identify the underlying events and the structures (or mechanisms) that generate these experiences within the specific contexts to draw out effective ways forward. Though it is a loose movement or meta-theoretical position encompassing different versions and phases, commonalities lie in a transcendental view of reality as independent of the human mind and critically viewing science as a human activity (See Archer et al., 2016; Gorski, 2013 for helpful introductions. Archer, Bhaskar, Collier, Lawson, \& Norrie,1998; Ackroyd \& Fleetwood, 2000; Edwards, O’Mahoney, \& Vincent, 2014 contain some essential readings). Its use has featured little in educational leadership (Thorpe, 2014) with Corson 
(2000) and Egbo (2005), from their context of educational administration in Canada, being two of the few to address its possibilities. A brief overview follows of some critical realist ideas deployed later in this article starting with the view of ontology before moving to how structures operate in the social world and its distinctive emancipatory axiology.

\section{A realist ontology with three levels of reality.}

Critical realism holds a transcendentalist realist ontological position encompassing three levels or domains of a stratified reality that must exist for science and enquiry to be possible, namely the real, actual and empirical. The empirical is the most accessible comprising our experiences of what happens in the world. The actual contains the events which occur in the world both those we experience as well as those we do not, and the real also includes the hard to access mechanisms and structures which exist independently of our experience and the events they may, or may not, generate (Shipway, 2011). This ontological stance is transcendental because reality transcends our experience of it. Barnett (2013) illustrates this multi-layered reality though the example of universities. At the empirical level, an individual experiences a university within a specific geo-historical context; the actual contains the immediate forms that universities have taken in the world which may, or may not, be experienced by an individual; and the real level encompasses the underlying, deep structures in which universities have their being.

These layers are often 'out of phase' in our experience so the scientific quest lies in uncovering the tendencies and powers of entities rather than seeking regulatory laws for events as positivism does (Gorski, 2013). Bhaskar (1978, p.95) gives an example when he says 'It is true that the path of my pen does not violate any laws of physics. But it is not determined by any either'. Critical realists recognise that social systems are open ones because entities emerge at different levels from complex relationships between multiple agents and structures where powers and tendencies are both actualised and not. 
A failure to distinguish epistemology from ontology leads to an erroneous view of science disposed to reductionism and decontextualization through the epistemological fallacy that constrains everything that can exist to that which can be empirically known. Critical realism holds its transcendental realist ontology with a relativist epistemology that eschews positivist and interpretivist assumptions but does not reject their research methodologies wholesale so promoting methodological pluralism (Kempster \& Parry, 2011; Scott, 2011). Critical realism's ontological view has led some to argue for an epistemology which is usually more associated with qualitative research approaches starting with the description of context, rather than seeing it as a rehabilitation of quantitative methodologies (Al-Amoudi \& Willmott, 2011).

Social science research should start with non-positivist methods as people's accounts constitute basic evidence due to the casual efficacy of the reasons within those accounts. Action and implementation involves people making decisions based on reasons, knowledge and values so critical realist research recognises 'the interaction of a real environment with the casually efficacious interior world of the individual agent' (Shipway, 2011, p.176). For Egbo (2005), critical realism enables people's accounts to be considered as valid research data to identify the structures around us containing reasons which are also causes and that emancipation and social transformation are the legitimate ends of research.

Structures in the social world and an emancipatory axiology.

Critical realism's stratified and differentiated conception of reality allows a focus on underlying structures or mechanisms at different levels (real and actual) starting with identifying observable experiences and the actual events which they have generated. The terms structures and mechanisms are used by critical realist writers seemingly interchangeably but Gorski (2013) notes a more recent preference for the former as the latter can be interpreted as indicating a misleading sense of stasis and repetition. However, the use of the phrase generative mechanisms remains popular to signal the emergent 
activity within and between levels. These structures are neither phenomena nor human constructs but are real in the physical and social world, which 'endure and operate independently of our knowledge, our experience and the conditions which allow us to assess them' (Bhaskar, 1978, p.25). For example, Alderson $(2013,2015)$ deploys these insights about structures to uncover how the experiences and capabilities of children are both marginalized and frequently ignored in research as well as public policy when adults prioritise their own interests over those of children to pursue their own theories, policies and goals. She identifies constraining absences, fallacies and generalizations in existing views so enabling the presentation of a new framework for studying and understanding children.

The distinction between the transitive dimension (containing our provisional and fallible concepts) and the intransitive dimension (the world as it really is) is related to the transcendental realist stance in which the latter contains structures each with its own powers and tendencies that are casually efficacious, whilst the former contains the historical and cultural theories that attempt to explain the real (Shipway, 2011). Yet caution must be exercised about our knowledge of the specifics of structures acknowledging the difficulties of identifying and describing them (Archer et al., 2016). Hence, Clegg (2005) deploys critical realism to show how systematic reviews that draw on evidence-based practice in educational research undermine professional autonomy but that the methodology could be transformed into something critical and emancipatory.

Critical realism shares a post-positivist critique with, for example, critical theory but departs over matters of ontology and structures leading to a transformative concept of agency and praxis based on the idea of absence (Shipway, 2011). The concept of absence is contrasted with difference. It is an ontologically reality rather than the non-existence of something. Absence and absenting represent ills that entail falsehoods and constraints. Absence drives the emergence of an agenda of change through the endeavours of 'constraining constraints' and 'absenting absences' (Shipway, 2011, p.183). This emancipatory axiology values human 
well-being and flourishing (axiology being the study of value and what is valued above another). It is linked to a judgemental rationality and cautious ethical naturalism that does not see all criteria for accounts of the world as equal but does assert that some ideas might be better than others to promote human flourishing whilst rejecting a simplistic move from 'is' to 'ought' (Archer et al., 2016; Gorski, 2013).

Recognising the distinction and constant tension between agency and structure avoids the domination of one by the other enabling an emancipatory axiology that promotes agency whilst recognising its limits. Archer's critical realist morphogenetic approach (1995) shows how structures in the social order act to condition, without determining, the social interactions that lead to structural modification. Using a historical form of analysis, she uncovers elaboration within centralised and decentralised educational systems (Archer, 1997). The morphogenetic approach has also been used to outline new ways to consider curriculum theory and change (Priestley, 2011) and to examine clashes between childcentred philosophy and the new managerialism played out in primary school case studies leading to teachers acting against their beliefs, in part, by not exercising the agency that they did have to resist (Willmott, 2002).

Current ideas of the university are interrogated by Barnett (2013) through a critical realist enabled imagining to realise their potential for human flourishing rather than being trapped within discourses of despair. The emancipatory potential of critical realism is also used by Shipway (2011) to illuminate educational theory and the enterprise of education as it relates to children, young people and teachers. Corson's (2000) work advocating emancipatory leadership for educational administrators has undertones of his previous overtly critical realist writings (Corson, 1991, 1995, 1998) which Egbo (2005) builds on as she proposes critical realism's strengths being its pluralist methodology and attention to promoting social justice in educational administration. The links to grounded theory and leadership learning in the lived lives of managers are explored by Kempster and Parry (2011) but critical realist 
approaches have played only a marginal role in feminist and gender studies (Gunnarsson, Martinez Dy, \& van Ingen, 2016). The next section considers how the critical realist ideas outlined above might be applied to the specific area of educational leadership development programmes and women.

\section{Critical realist insights for educational leadership development and women.}

The three insights explored below emerge from the contextual nature of educational leadership, the understanding of structure as real but mutable, and the use of emancipatory tools to provide ways to distinguish what is empowering in leadership development programmes from what is constraining. They reflect critical realism's acknowledgment of provisionality and fallibility so will disappoint those seeking definitive prescriptions based on claims to simplistic causal regularities.

i. A critical realist ontology brings an understanding of the contextual nature of educational leadership which has implications for the theory of educational leadership and the content of programmes and activities.

Critical realism identifies the reductionism of, for example, new managerialism and leaderism that diminish educational leadership and its development to prescribed technological procedures and methods. Instead, educational leadership and its development comprises a distinctive set of geo-historical events and phenomena involving agents and structures with powers and tendencies accessible first through the empirical level. Developing Egbo (2005), the accounts from practitioners of educational leadership are distinct from those of students, classroom teachers, learning support assistants and policy makers. They cannot be subsumed, or reduced, within a teleology of student achievement or a subsection of decontextualized general leadership theory and skills though there may be similarities between contexts. 
Therefore, educational leadership and leadership development is only discernible in context and not as abstracted, positivist normative propositions and prescriptions. Educational leadership development programmes can start with contextualised accounts of practitioners, most obviously those of the programme participants themselves, rather than traditional heroic stories of mainly male chief executives. In this way women's accounts need not be ignored and concealed and educational leadership practice emerges as an entity through specific geo-historical contexts (Gorski, 2013; Kempster \& Parry, 2011).

ii. The critical realist understanding of structures as real and significant means that they can also be challenged through, amongst other things, leadership development programmes. The understanding of enduring structures of education organizations and society, and how they both enable and limit agency, opens new ways to explore educational leadership practice and therefore what educational leadership development might be. The stratified ontology and understanding that structures are not solid reveals how there can be a leadership turn in education which is real and potent (Morley, 2013). O'Reilly and Reed's (2010) explicitly critical realist work identifies how new managerialism's disguise of leaderism further decontextualizes practice in the public sector so changing the structures which give rise to leadership events and experiences. These structures are independent of, and not contingent upon, the agents including both the participants on the programmes and those organizing the programmes.

A critical realist ontological position highlights the shortcomings of too great an emphasis on individual agency at the expense of structure. People cannot simply 'pull themselves together' to fully control their situation. For example, recognising how agency and structure are always in tension helps in identifying those micro-inequities and often unexpected biases by which discrimination operates and affects educational leadership development and participation, including who is offered development opportunities and what those opportunities are (Hoobler et al., 2014). Critical realism provides a fuller understanding, with 
a greater internal consistency than positivism and interpretivism, as to why these concerns and frustrations persist. The misalignment of the levels of reality explains, without resolving, the apparent paradox that Debebe et al. (2016) report where many women express feelings of being both enabled and restricted in their leadership practice. Lynch et al. (2012) identify a need to go beyond seeking psychological feelings or understandings which are often the concerns of research in this area and it is critical realism's ontological stance that shows how similar feelings re-occur because the underlining structures remain the same or, where change has occurred at one level, the complexities that cause emergence thwart progress. Hence, it is more pertinent to explore how women are represented and their practice within the institutional structures rather than focusing solely on numbers as the events and structures are only discernible in these contexts (Fitzgerald, 2014; Hoobler et al., 2014; Thorpe, 2016).

Whilst the difficulties in changing social reality should not be underestimated, neither should a defeatist view of structuralism be adopted. Critical realism's emancipatory axiology shows not only how the structures of the carelessness discourse and safe solutions in educational leadership (Lynch et al., 2012) are generated and maintained but also that they can be challenged. There can be a real change in language which has an impact on behaviour and reality so this 'turn' can itself be turned. It is the way people talk about the events and their views that reflects, as well as influences, the real as, 'we can change or remove structures or we can strengthen them by the things we say and do in local settings' (Corson, 1998, p.4).

Archer's morphogenetic approach shows how knowledge and ideas might be active or currently asleep to be activated at a later date, for example, the structures of caring in education (Lynch et al., 2012) do not cease to exist even though they may not be generative in the present time. Enabling structures from the past to be drawn upon presents ways to be liberated from claims of those in power that there is only one logical, technical direction for 
the development of educational leadership practice and the type of research that should be conducted.

iii. Critical realist tools of emancipation provide ways to distinguish what is empowering in leadership development programmes from what is constraining, and to identify what may support the emancipation of those programmes and delegates.

The critical realist conception of structures as real things provides tools to see why initiatives in educational organizations, such as leadership development programmes, might both enable but also thwart the promotion of equality, diversity and inclusion. New managerialism seeks to produce correct action on a continual and all-consuming basis which involves educational leaders implementing changes to promote the neo-liberal project repositioning education as a marketable service (Lynch et al., 2012). Educational leadership development is a potential generative mechanism for this repositioning and converting post holders to be those willing champions.

Women only educational leadership programmes (and other modes for that matter) present an opportunity to disrupt established views and challenge them if they equip people appropriately. The optimism of Ely et al. (2011) and Debebe et al. (2016) about the approach of women only programmes should be welcomed for its belief in efficacious action for transformative change. Yet the aim of transformation learning to 'disorient' participants equally allows for influence within the leadership turn as much as it provides opportunities for reflexivity to recognise it at work. The programmes may not be as authentic as hoped because the situated topics and tools will not be free of the ontological social realities, whilst the generative mechanisms of the current leadership discourse are still there underneath the events and experiences.

Critical realist tools are needed by programme participants and those running the programmes. The importance of equipping people to unmask theoretical fallacies, empirical 
overgeneralizations and absences in childhood studies can also be applied to educational leadership programmes (Alderson, 2013, 2015). Shipway (2011) writes about how school teachers must be involved in their own emancipation before emancipating others and they need tools for self-emancipation to be able to delineate between empowering aspects and hegemonic ones. The tools he identifies of reflection, evaluation, self-criticality and collegiality, rather than tools for participating in the promotion of power hierarchies, are equally valuable for educational leadership programmes. Critical realism's adherence to judgemental rationality and cautious ethical naturalism allows for more and better ideas according to Barnett (2013) with the task of leadership being to enable new imaginings and convert these into policies and practices. Educational leadership development programmes need to equip participants with an understanding of this task and how it might be achieved but this will need facilitation by reflective, critical and reflexive people (Kempster and Parry, 2011).

Those devising and running leadership development programmes should constantly review (as once is not enough due to the shifting nature of structures and emergence) whether their development programmes are maintaining the 'status quo' or implementing safe solutions so avoiding engagement in emancipatory change. Such reviews should involve challenging reductionist ideas of leadership in development programmes. Intersectionality can be seen within a critical realist understanding that acknowledges the limitations of contemporary debates and provides a better methodological approach for providing causal explanatory accounts of people's experiences (Martinez Dy et al., 2014) to uncover injustices and examples of inequity which thwart progress and mean the same experiences and frustrations continue to emerge from research.

\section{Conclusion}

This article has explored the potential of critical realism, hitherto rarely used in educational leadership research, to provide a greater understanding of educational leadership 
development and women. Significantly, it contributes to illuminating current situations of discrimination in the ongoing under-representation of women as leaders in educational environments and what might be involved in challenging this state of affairs as they relate to educational leadership development. Critical realism's stratified transcendentalist realist ontology provides not only a fuller understanding as to why these concerns and frustrations persist in relation to women and educational leadership and its development but also enables ways forward through its emancipatory axiology. The emancipatory axiology provides the tools for a fundamental challenge to, and changing of, the dominant concept of educational leadership so progress can be made on equality, diversity and inclusion in educational leadership theory and practice.

Further theoretical and empirical research is needed to explore how to constrain disabling discourses. Such research might involve a re-imagining of the practice and its development in the vein of Barratt's critical realist work in the context of universities seeking a vocabulary of hope and emancipation 'ontologically rooted and imaginatively flying, all at once' (2013, p.123) and Morley's (2013) call for a new lexicon of educational leadership. However, the critical realist orientation towards emancipation for all may well disappoint those seeking guaranteed strategies to obtain positions for themselves in the upper echelons of the hierarchy whilst preserving and legitimizing current dominant ideas of educational leadership.

The caveat of the article's introduction about drawing largely on UK, Irish, North American and Australasian literature with their specific concerns and content suggests work in different contexts is required. However, this article's focus is deliberate as critical realism works by looking at specific situations in order to reach the other levels of reality and therefore is wary of sweeping statements based on decontextualized literature and research (Clegg, 2005). Returning to the second caveat, applying critical realism can contribute to constraining the decontextualization that decouples people from practice by recognizing both the practice and 
the practitioners, as well as the theorists, are within a context involving real agency and structures. By raising questions and identifying possibilities rather than seeking to provide simplistic and definitive sounding answers, I hope that others will consider the use of critical realism in research about educational leadership development and women as well as in the wider field.

\section{References}

Ackroyd, S., \& Fleetwood, S. (Eds.) (2000). Realist perspectives on management and organisations. London: Routledge.

Al-Amoudi, I., \& Willmott, H. (2011). Where constructionism and critical realism converge: Interrogating the domain of epistemological relativism. Organization Studies, 32, 2746.

Alderson, P. (2013). The politics of childhoods, real and imagined: Volume 1: An introduction to critical realism and childhood studies. London: Routledge.

Alderson, P. (2015). The politics of childhoods, real and imagined: Volume 2: Practical application of dialectical critical realism and childhood studies. London: Routledge.

Alvesson, M., Bridgman, T., \& Willmott, H. (2011) The Oxford Handbook of Critical Management Studies. Oxford: Oxford University Press.

Archer, M. (1995). Realist social theory: the Morphogenetic approach. Cambridge: Cambridge University Press.

Archer, M. (1997). Social origins of educational systems. London: Routledge.

Archer, M., Bhaskar, R., Collier, A., Lawson, T., \& Norrie, A. (Eds.) (1998). Critical realism: essential readings. Abingdon: Routledge.

Archer, M., Decoteau, C., Gorski, P., Little, D., Porpora, D., Rutzou, T., ... Vandenberghe, F. (2016). What is critical realism? Perspectives: A newsletter of the theory section (American Sociological Association). December. Retrieved from http://www.asatheory.org/current-newsletter-online/what-is-critical-realism 
Arnold, N., \& Brooks, J. (2013). Getting churched and being schooled: Making meaning of leadership practice. Journal of Cases in Educational Leadership, 16, 44-53.

Barnard, S., Arnold, J., Bosley, S. \& Munir, F. (2016) Onwards and upwards? Tracking women's work experiences in higher education. Year 1 Report. Leadership Foundation for Higher Education. Retrieved from https://www.lfhe.ac.uk/en/researchresources/research-hub/2016-research/index.cfm

Barnett, R. (2013). Imagining the university. Abingdon: Routledge.

Barrett, L., \& Barrett, P. (2011). Women and academic workloads: Career slow lane or Culde- Sac? Higher Education, 61, 141-155.

Beddington, D. (2009). Diversity in higher education: leadership responsibilities and challenges. Final Report. London: Leadership Foundation for Higher Education. Retrieved from https://www.Ifhe.ac.uk/en/components/publication.cfm/S2-02

Bhaskar, R. (1978). A reality theory of science (2 $2^{\text {nd }}$ ed.). Brighton: Harvester Press.

Blackmore, J. (2010) Editorial. Special issue: Disrupting notions of leadership from feminist post-colonial positions. International Journal of Leadership in Education, 13, 1-6.

Blackmore, J., Thomson, P., \& Barty, K. (2006). Principal selection: Homosociability, the search for security and the production of normalized principal identities. Educational Management Administration and Leadership, 34, 297-317.

Billing, Y. D., \& Alvesson, M. (2000). Questioning the notion of feminine leadership. A critical perspective on the gender labelling of leadership. Gender, Work \& Organization, 7 , 144-157.

Boerema, A. (2011). Challenging and supporting new leader development. Educational Management Administration and Leadership, 39, 554-567.

Bogotch, I., \& Shields, C. M. (Eds.) (2014). International handbook of educational leadership and social (in)justice volume 1. London: Springer.

Capper C. A., \& Young, M. (2014). Ironies and limitations of educational leadership for social justice: A call to social justice educators. Theory Into Practice, 53, 158-164. 
Catalyst (2016). 2015 Catalyst census: Women and men board directors. New York: Catalyst.

Clegg, S. (2005). Evidence-based practice in educational research: a critical realist critique of systematic review. British Journal of Sociology of Education, 26, 415-428.

Close, P., \& Raynor, A. (2010). Five literatures of organisation: putting the context back into educational leadership. School Leadership \& Management, 30, 209-224.

Coate, K., Kandiko Howson, C. B., \& de St Croix, T. (2015). Mid-career academic women: Strategies, choices and motivation. London: Leadership Foundation for Higher Education.

Coleman, M. (2010). Women-only (homophilous) networks supporting women leaders in education. Journal of Educational Administration, 48, 769-781.

Colley, H. (2001). Righting rewritings of the myth of Mentor: A critical perspective on career guidance mentoring. British Journal of Guidance and Counselling 29, 177-197.

Corson, D. J. (1991). Bhaskar's critical realism and educational knowledge. British Journal of Sociology of Education, 12, 223-241.

Corson, D. J. (ed.) (1995). Discourse and power in educational organizations. Michigan: Hampton Press.

Corson, D. J. (1998). Changing education for diversity. Buckingham: Open University Press.

Corson, D. J. (2000). Emancipatory leadership. International Journal of Leadership in Education, 3, 93-120.

Cullen-Lester, K. L., Woehler, M. L., \& Willburn, P. (2016). Network-based leadership development: A guiding framework and resources for management educators. Journal of Management Education, 40, 321-358.

Debebe, G., Anderson, D., Bilimoria, D., \& Vinnicombe, S. M. (2016). Women's leadership development programs: Lessons learned and new frontiers. Journal of Management Education, 40, 231-252.

Dever, M., Boreham, P., Haynes, M., Kubler, M., Laffan, W., Behrens, K., \& Western, M. (2008). Gender differences in early post PhD employment in Australian Universities: 
The influence of PhD experience on women's academic careers. Brisbane: University of Queensland Social Research Centre (UQSRC).

Devos, A. (2008). Where enterprise and equity meet: The rise of mentoring for women in Australian universities. Discourse: Studies in the Cultural Politics of Education, 29, 195-205.

Eacott, S. (2015). Educational leadership relationally: a theory and methodology for educational leadership, management and administration. Rotterdam: Sense Publishers.

Edwards, P., O’Mahoney, J., \& Vincent, S. (Eds.) (2014). Studying organizations using critical realism: a practical guide. Oxford: Oxford University Press.

Egbo, B. (2005). Critical Realism and transformative research in educational administration. McGill Journal of Education, 40, 267-284.

Elliott, C., \& Stead, V. (2017). Constructing Women's Leadership Representation in the UK Press During a Time of Financial Crisis: Gender capitals and dialectical tensions. Organization Studies, Online DOI: 10.1177/0170840617708002.

Ely, R. J., Ibarra Insead, H., \& Kolb, D. M. (2011). Taking gender into account: Theory and design for women's leadership development programs. Academy of Management Learning and Education, 10, 474-493.

Fitzgerald, T. (2014). Women Leaders in Higher Education Shattering the Myths. London: Routledge \& SRHE.

Fuller, K. (2017). Women secondary head teachers in England: where are they now? Management in Education, 31, 54-68.

Glatter, R. (2006). Leadership and organization in education: Time for a re-orientation? School Leadership and Management, 26, 69-83.

Gorski, P. S. (2013). What is Critical Realism? And why should you care? Contemporary Sociology, 42, 658-670.

Grace, G. (1995). School Leadership- beyond education management: an essay in policy scholarship. London: Falmer Press. 
Grogan, M., \& Shakeshaft, C. (2011). Women and educational leadership. San Francisco, CA: Jossey Bass.

Grummell, B., Devine, D., \& Lynch, K. (2009). The careless manager: Gender, care and new managerialism in higher education. Gender and Education, 21, 191-208.

Griffiths, V. (2009). Women Managers in higher education: experiences from the UK. International Journal of Learning, 16, 397-405.

Guillaume, C., \& Pochic, S. (2009). What would you sacrifice? Access to top management and the work-life balance. Gender, Work \& Organization, 16, 14-36.

Gunnarsson, L., Martinez Dy, A., \& van Ingen, M. (2016). Critical realism, gender and feminism: exchanges, challenges, synergies. Journal of Critical Realism, 15, 433439.

Gunter, H. M. (2011). Educational Leadership and the reform of education. Bristol: Policy Press.

Gunter, H. M., \& Thomson, P. (2009). The makeover: A new logic in leadership development in England? Educational Review, 61(4), 469-483.

Hoobler, J. M., Lemmon, G., \& Wayne, S. J. (2014). Women's managerial aspirations: An organizational development perspective. Journal of Management, 40, 703-730.

Ibarra, H., Carter, N. M., \& Silva. C. (2010). Why men still get more promotions than women. Harvard Business Review, 88, 80-85.

Kempster, S. \& Parry, K. W. (2011) Grounded theory and leadership research: A critical realist perspective. The Leadership Quarterly, 22, 106-120.

Lynch, K. (2014). New managerialism: the impact on education. Concept: The Journal of Contemporary Community Education Practice Theory, 5, 1-11.

Lynch, L., Grummell, B., \& Devine, D. (2012). New managerialism in education: Commercialization, carelessness, and gender. New York: Palgrave Macmillan.

Lyness, K. S., \& Thompson, D. E. (2000). Climbing the corporate ladder: Do female and male executives follow the same route? Journal of Applied Psychology, 85, 86-101. 
Mabey, C. (2013). Leadership development in organizations: Multiple discourses and diverse practice. International Journal of Management Reviews, 15, 359-380.

Martinez Dy, A., Martin, L., \& Marlow, M. (2014). Developing a critical realist positional approach to intersectionality. Journal of Critical Realism, 13, 447-466.

McKeen, C., \& Bujaki, M. (2007). Gender and mentoring. In Ragins, B.R. \& Kram, K.E. (Eds.) The handbook of mentoring at work: Theory, research, and practice. Los Angeles: Sage, 197- 222.

Moorosi, P. (2012). Mentoring for school leadership in South Africa: diversity, dissimilarity and disadvantage. Professional Development in Education, 38, 487-503.

Moorosi, P. (2013). Constructing a leader's identity through a leadership development programme: An intersectional analysis. Educational Management Administration \& Leadership, 42, 792-807.

Morley, L. (2013). The rules of the game: women and the leaderist turn in higher education. Gender and Education, 25, 116-131.

Niesche, R., \& Keddie, A. (2011). Foregrounding issues of equity and diversity in educational leadership. School Leadership \& Management, 31, 65-77.

O'Brien, M. (2007). Mothers' emotional care work in education and its moral imperative. Gender and Education, 19, 159-177.

O’Reilly, D., \& Reed, M. (2010). 'Leaderism': An evolution of managerialism in UK public service reform. Public Administration, 88, 960-78.

Priestley, M. (2011). Whatever happened to curriculum theory? Critical realism and curriculum change. Pedagogy, Culture \& Society, 19, 221-237.

Runte, M., \& Mills, A. J. (2004). Paying the toll: A feminist post-structural critique of the discourse bridging work and family. Culture and Organization, 10, 237-249.

Santamaría, L. J., \& Gaëtane J-M (2014). Cross-cultural dimensions of applied, critical, and transformational leadership: women principals advancing social justice and educational equity. Cambridge Journal of Education, 44, 333-360. 
Schein, V. E. (1973). The relationship between sex role stereotypes and requisite management characteristics. Journal of Applied Psychology, 57, 95-100.

Scott, D. (2011). Education, epistemology and critical realism. London: Routledge.

Senge, P. (1999). The leadership of profound change: towards an ecology of leadership. In Senge, P., Kleiner, A., Roberts, C., Ross, R., Roth, G., and Smith, B. (Eds.), The Dance of change: the challenges of sustaining momentum in learning organizations (pp. 10-21). London: Nicholas Brealey.

Shepherd, S. (2017). Why are there so few female leaders in higher education? Management in Education, 31, 82-87.

Shipway, B. (2011). A critical realist perspective of education. London: Routledge. Showunmi, V., Atewologun, D., \& Bebbington, D. (2015). Ethnic, gender and class intersections in British women's leadership experiences. Educational Management Administration \& Leadership, 44, 917-935.

Smith, J. (2011). Aspirations to and perceptions of secondary headship: contrasting female teachers' and headteachers' perceptions. Educational Management Administration \& Leadership, 39, 516-535.

Sugiyama, K., Cavanagh, K. V., van Esch, C., Bilimoria, D., \& Brown, C. (2016). Inclusive leadership development: Drawing from pedagogies of women's and general leadership development programs. Journal of Management Education, 40, 253-292.

Thorpe, A. (2014, July). A critical realist approach to educational leadership and management: possibilities and agendas. A paper presented at the International Association of Critical Realism Conference, London.

Thorpe, A. (2016). Women and Leadership: a thematic review of literature from the education sector. Project Report. The Susanna Wesley Foundation. Retrieved from http://susannawesleyfoundation.org/wp-content/uploads/2016/02/Anthony-Thorpe.pdf

Thrupp, M., \& Willmott, R. (2003). Education management in managerialist times: Beyond the textual apologists. Maidenhead: Open University Press. 
Torrance, D., \& Humes, W. (2015). The shifting discourses of educational leadership: International trends and Scotland's response. Educational Management Administration \& Leadership, 43, 792-810.

Willmott, R. (2002). Education policy and realist social theory: primary teachers, childcentred philosophy and the new managerialism. London: Routledge.

Wilkinson. J., \& Eacott, S. (2013). Introduction: These disruptive times: Rethinking critical educational leadership. International Journal of Leadership in Education, 16, 135138. 